\title{
PERUBAHAN MORFOLOGI RUANG PADA SEGMEN I KORIDOR SIS AL-JUFRI KOTA PALU DAN FAKTOR YANG MEMPENGARUHINYA
}

\section{CHANGES OF SPATIAL MORPHOLOGY IN SEGMENT I SIS AL-JUFRI CORRIDOR, PALU CITY AND THE CONTRIBUTING FACTOR OF THE CHANGES}

\author{
Sri Wulandari', Wisnu Pradoto ${ }^{2}$ \\ 'Dinas Penataan Ruang dan Pertanahan Kota Palu; Jl. Balaikota Selatan No.1; wulanjiks@outlook.com \\ ²Departemen Perencanaan Wilayah dan Kota; Universitas Diponegoro, Semarang, Jawa Tengah; wisnu.pradoto@gmail.com
}

Info Artikel:

- Artikel Masuk: 13/02/2018

- Artikel diterima: 28/06/2018

- Tersedia Online: 24/08/18

\begin{abstract}
ABSTRAK
Berdasarkan RTRW Kota Palu Tahun 2010 - 2030, Koridor Sis Al-Jufri ditetapkan sebagai kawasan wisata religi dengan keberadaan Yayasan Pendidikan Al-Khairaat sebagai aktivitas utama. Keberadaan koridor ini juga terdapat berbagai aktivitas pendukung seperti aktivitas ekonomi / perdagangan, sosial kemasyarakatan dan kesehatan dan peribadatan. Dengan beragam aktivitas didalamnya, sehingga dapat menyebabkan terjadinya perubahan morfologi ruang pada koridor Sis Al-Jufri, seperti perubahan peruntukan lahan dari permukiman menjadi kawasan perdagangan dan jasa, terdapat beberapa bangunan hunian berubah fungsi menjadi bangunan komersial untuk kegiatan perdagangan dan jasa mengikuti tuntutan pasar. Pendekatan penelitian menggunakan pendekatan kuantitatif dengan analisis deskriptif digunakan untuk mengidentifikasi perubahan morfologi ruang yang terjadi pada koridor Sis Al-Jufri, analisis regresi logistik digunakan untuk mengetahui pengaruh faktor sosial, faktor ekonomi dan faktor kebijakan terhadap perubahan morfologi ruang pada koridor Sis Al-Jufri.Hasil dari penelitian ini adalah perubahan morfologi ruang yang terjadi di Koridor Sis Al-Jufri mengalami perubahan sebesar 34,46\% dan faktor-faktor yang mempengaruhi perubahan morfologi ruang pada Koridor Sis Al-Jufri saat ini secara signifikan adalah lama bermukim, kepemilikan bangunan, pekerjaan, kepemilikan IMB, dan pengaturan GSB.

Kata kunci : Perubahan, Morfologi, Koridor, Sis Al-Jufri
\end{abstract}

\section{ABSTRACT}

Based on Palu City Urban Planning (RTRW) 2010 - 2030, Sis Al-Jufri Corridor designated as a religious tourism area with the existence of Al-Khairaat Education Foundation as the center of the activity. The corridor also provide a platfrom to support various activities such as economic activities / trade, social and health and worship activities. Diverse activities in the corridor contributes to changes in its space morphology, such as changes in landuse from settlements into commercial areas and services. Some residential buildings changed its function into commercial buildings for trading activities and services to fulfill market demands. Research approach using quantitative approach with descriptive analysis used to identify morphological changes that occur in Sis Al-Jufri Corridor, logistic regression analysis used to determine the influence of social factors, economic factors and policy factors on changes in space morphology in the corridor. The result of this study is the change of space morphology that occurred in Sis Al-Jufri Corridor experienced a change of $34.46 \%$. The factors affecting spatial morphology changes in Sis Al-Jufri Corridor are length of staying, ownership of buliding, job type, building license (IMB) ownership, and setback of buliding.

Keyword: Change, Morphology, Corridor, Sis Al-Jufri

Copyright $\odot 2018$ JPWK-UNDIP This open access article is distributed under a Creative Commons Attribution (CC-BY-NC-SA) 4.0 International license.

Cara men-sitasi (APA 6th Style):

Wulandari, Sri., \& Pradoto, Wisnu. (2018).Perubahan Morfologi Ruang pada Segmen I Koridor Sis Al-Jufri Kota Palu dan Faktor yang Mempengaruhinya. Jurnal Pembangunan Wilayah dan Kota, Vol 14 (2), 131 - 142 


\section{PENDAHULUAN}

Koridor sebagai ruang kota membantu manusia bergerak dari ruang kota satu ke ruang kota yang lain, dengan potensi tersebut koridor harus memiliki potensi yang dibutuhkan manusia, yaitu dimana manusia merasakan adanya ruang yang terus melingkupinya serta sadar akan keberadaannya. Sebuah koridor yang berkarakter ditunjang oleh pengaturan ruang koridor dan juga hal-hal yang masih berkaitan dengan orientasi dan estetika yang dimunculkan oleh koridor itu sendiri, sebuah koridor dapat menjadi sebuah segmen kota. Fungsi koridor sebagai lingkage/ penghubung dan generator tidak lepas dari pengaturan sirkulasi dan parkir (Shirvani, 1985). Suatu koridor dibagian pusat kota berkembang menjadi kawasan perdagangan disebabkan faktor penunjang keberadaan lokasi tersebut, antara lain kedekatan, kemudahan, ketersediaan dan faktor kenyamanan, selain itu ditentukan pula oleh meningkatnya jumlah penduduk disekitar kawasan serta peningkatan pendapatan perkapita masyarakat dan adanya fasilitasfasilitas yang menunjang kawasan.

Koridor Sis Al-Jufri merupakan salah satu ruang publik yang menjadi bagian dari pusat Kota Palu yang tidak terlepas dari perkembangan secara fisik tata ruang dan bangunannya, berdasarkan RTRW Kota Palu Tahun 2010 -2030 ditetapkan sebagai kawasan wisata religi dengan fungsi peruntukkan kawasan permukiman, perdagangan dan jasa. Perkembangan koridor Sis Al-Jufri dan sekitarnya dengan aktivitas khusus yang bernuansa religi, memiliki peranan penting dalam perkembangan sejarah Kota Palu. Koridor Sis Al-Jufri sangat berpotensi untuk menjadi salah satu ikon kota, karena keragaman fungsi ruang kota yang ada pada koridor. Sebagai kawasan wisata religi dengan keberadaan Yayasan Pendidikan Al-Khairaat sebagai aktivitas utama, keberadaan koridor ini juga terdapat berbagai aktivitas pendukung seperti aktivitas ekonomi / perdagangan, sosial kemasyarakatan dan kesehatan. Timbulnya banyak aktivitas disepanjang koridor tersebut akan meningkatkan kualitas dari koridor itu sendiri sehingga akan mudah dikenali orang. Keberadaan koridor mengalami perkembangan yang berbeda-beda disebabkan karena pemusatan aktivitas dan perkembangan transportasi, sehingga mempengaruhi terjadinya perubahan fungsi pada koridor tersebut. Koridor Sis Al-Jufri merupakan sebuah koridor mayoritas dihuni oleh komunitas masyarakat Arab dengan aktivitas perdagangan dan jasa yang terbentuk oleh deretan ruko-ruko dengan fasad bangunan yang lebih modern, sehingga menyebabkan terjadinya perubahan morfologi ruang koridor sebagai kawasan religi.

Hal tersebut terjadi karena adanya aktivitas ekonomi yang tinggi dan intervensi kebijakan dari pemerintah kota dengan segala peraturannya mengakibatkan koridor sebagai salah satu ruang publik kota menjadi hilang bahkan berubah fungsinya. Perubahan tata guna lahan dari fungsi permukiman berubah menjadi peruntukkan perdagangan dan jasa, menjamurnya pembangunan ruko-ruko pada koridor ini dikhawatirkan akan mempengaruhi keberadaannya sebagai kawasan wisata religi, karena fasad bangunan menjadi lebih modern. Kemudian bangunan yang ada pada koridor ini telah berubah ukuran dan fungsi dari hunian menjadi bangunan komersil. Beberapa bangunan semi permanen yang dibangun tanpa mempertimbangkan garis sempadan yang telah ditetapkan pada koridor ini. Terkait uraian tersebut, maka penelitian ini dimaksudkan untuk mengendalikan pemanfaatan ruang untuk mengurangi dampak terhadap perubahan morfologi ruang pada koridor Sis Al-Jufri dan mengetahui faktor-faktor yang mempengaruhi perubahan morfologi ruang koridor.

\section{DATA DAN METODE}

2.1 Data

Data dan informasi yang dibutuhkan berdasrkan analisis yang dilakukan pada penelitian ini berasal dari data primer dan data sekunder. Data primer diperoleh di lapangan berdasarkan hasil observasi / pengamatan, dan data hasil kuesioner yang ditampilkan dalam bentuk gambar, tabel, diagram atau grafik. Data sekunder diperoleh dari instansi yang terkait dengan tema penelitian berupa peta dan dokumen pendukung lainnya pada instansi terkait seperti BAPPEDA Kota Palu, Dinas Penataan Ruang dan Pertanahan Kota Palu, BPS Kota Palu, Kelurahan Siranindi, Kelurahan Boyaoge dan instansi lainnya yang 
terkait dengan kawasan wisata religi terutama koridor Sis Al-Jufri. Mengenai kebutuhan data yang diperlukan dalam penelitian ini akan dirangkum dalam tabel $\mathbf{1}$ berikut ini :

Tabel 1. Kebutuhan Data (Hasil Analisis, 2017)

\begin{tabular}{|c|c|c|c|c|c|}
\hline NO. & SASARAN & KEBUTUHAN DATA & $\begin{array}{c}\text { CARA } \\
\text { MEMPEROLEH } \\
\text { DATA }\end{array}$ & SUMBER DATA & OUTPUT \\
\hline 1. & $\begin{array}{l}\text { Mengidentifikasi } \\
\text { dan menganalisis } \\
\text { perubahan } \\
\text { morfologi ruang } \\
\text { pada koridor Sis Al- } \\
\text { Jufri }\end{array}$ & $\begin{array}{l}\text { - Penggunaan lahan } \\
\text { - Fungsi bangunan } \\
\text { - Ketinggian } \\
\text { bangunan } \\
\text { - Tampilan bangunan } \\
\text { - Ukuran bangunan }\end{array}$ & $\begin{array}{l}\text { - Data Primer: } \\
\text { Kuesioner } \\
\text { dan } \\
\text { observasi } \\
\text { lapangan } \\
\text { - Data } \\
\text { Sekunder: } \\
\text { Survei } \\
\text { instansi, studi } \\
\text { literatur } \\
\text { - Dokumentasi }\end{array}$ & $\begin{array}{l}\text { - } \text { BAPPEDA Kota } \\
\text { Palu } \\
\text { - Dinas } \\
\text { Penataan } \\
\text { Ruang dan } \\
\text { Pertanahan } \\
\text { Kota Palu } \\
\text { - Responden }\end{array}$ & $\begin{array}{l}\text { Perubahan } \\
\text { morfologi ruang } \\
\text { pada koridor Sis } \\
\text { Al-Jufri dari tahun } \\
2005-2017\end{array}$ \\
\hline 2. & $\begin{array}{l}\text { Mengidentifikasi } \\
\text { dan menganalisis } \\
\text { faktor-faktor yang } \\
\text { mempengaruhi } \\
\text { perubahan } \\
\text { morfologi ruang } \\
\text { pada koridor Sis Al- } \\
\text { Jufri }\end{array}$ & $\begin{array}{l}\text { - Kondisi sosial } \\
\text { - Kondisi ekonomi } \\
\text { - Kebijakan pada } \\
\text { Koridor Sis Al-Jufri }\end{array}$ & $\begin{array}{l}\text { - Data Primer } \\
\text { Kuesioner } \\
\text { dan } \\
\text { observasi } \\
\text { lapangan } \\
\text { - Data } \\
\text { Sekunder } \\
\text { Survei } \\
\text { instansi, studi } \\
\text { literatur, } \\
\text { - Dokumentasi }\end{array}$ & $\begin{array}{l}\text { - } \text { BPS Kota Palu } \\
\text { - Kelurahan } \\
\text { Siranindi } \\
\text { - Kelurahan } \\
\text { Boyaoge } \\
\text { - } \text { BAPPEDA Kota } \\
\text { Palu } \\
\text { - Dinas } \\
\text { Penataan } \\
\text { Ruang dan } \\
\text { Pertanahan } \\
\text { Kota Palu } \\
\text { - Responden }\end{array}$ & $\begin{array}{l}\text { Faktor-faktor yang } \\
\text { mempengaruhi } \\
\text { perubahan } \\
\text { morfologi ruang } \\
\text { pada koridor Sis } \\
\text { Al-Jufri }\end{array}$ \\
\hline
\end{tabular}

\subsection{Metode}

Metode penelitian yang digunakan adalah metode kuantitatif dengan pendekatan positivistik untuk meneliti populasi atau sampel tertentu, pengumpulan data menggunakan instrumen penlitian, analisis data bersifat kuantitatif / statistik dengan tujuan menguji hipotesis yang ditetapkan (Sugiyono, 2015). Populasi dalam penelitian ini adalah bangunan yang berada di Koridor Sis Al-Jufri yang berjumlah sebanyak 59 unit bangunan. Adapun teknik pengambilan sampel dalam penelitian ini dalam penelitian ini adalah dengan menggunakan area sampling, yaitu pengambilan sampel berdasarkan pembagian wilayah penelitian dengan cara purposive sampling, yaitu bangunan yang berada pada lapis pertama yang terletak di Koridor Sis Al-Jufri .

Teknik analisis yang digunakan dalam penelitian ini adalah metode penelitian deskriptif kuantitatif. Analisis kuantitatif deskriptif yang digunakan dalam penelitian ini terkait dengan perubahan morfologi ruang koridor, diperlukan identifikasi awal mengenai perubahan penggunaan lahan, perubahan fungsi bangunan, perubahan tampilan bangunan, perubahan ketinggian bangunan, dan perubahan ukuran/ luasan bangunan. Dari identifikasi tersebut dapat diketahui perubahan morfologi ruang koridor yang terjadi secara time series dan diketahui faktor-faktor yang mempengaruhi perubahan morfologi ruang koridor, dan didukung dengan hasil olahan data kuesioner yang dilakukan. Selanjutnya menganalisis faktor yang mempengaruhi perubahan morfologi ruang koridor dengan melalui teknik statistik deskriptif menggunakan analisis regresi logistik. Regresi logistik merupakan salah satu bagian dari regresi yang 
digunakan untuk memprediksi variabel terikat (dependen) yang disimbolkan dengan $\mathrm{Y}$, yaitu perubahan morfologi ruang pada koridor Sis Al-Jufri yang berskala dikotomi dengan satu atau beberapa variabel bebas (independen) yang disimbolkan dengan $X$, yaitu faktor-faktor yang mempengaruhi perubahan morfologi ruang pada Koridor Sis Al-Jufri. Dalam menganalisis pengujian dengan menggunakan regresi logistik perlu menilai kelayakan model (goodness of fit test) dengan memperhatikan nilai signifikan Omnibus Test, $R$ Squared, serta Hosmer dan Lemeshow Test kemudian membuat persamaan regresi dan menilai Odds Ratio untuk menguji hipostesis, jika nilai sig $>0,05$ makan $\mathrm{H}_{0}$ diterima, berarti tidak ada pengaruh signifikan dari variabel $\mathrm{X}$ terhadap variabel $\mathrm{Y}$ dan jika nilai sig $<0,05$ maka $\mathrm{H}_{0}$ ditolak, berarti ada pengaruh signifikan dari variabel $X$ terhadap variabel $Y$ (Sarwono, $d k k, 2012$ ).

Penelitian ini berlokasi di Koridor Sis Al-Jufri, secara administratif berada di Kelurahan Siranindi dan Kelurahan Boyaoge Kecamatan Palu Barat dengan panjang jalan 551,77 meter dengan luas 7,00 Ha dan terdiri dari 59 unit bangunan. Karakteristik sosial budaya masyarakat di Koridor Sis Al-Jufri didominasi oleh etnis arab, kaili dan bugis. Berdasarkan arahan RDTR Kecamatan Palu Barat, Koridor Sis Al-Jufri merupakan bagian pusat perdagangan skala regional, yaitu dengan keberadaan Palu Plaza sebagai pusat perdagangan.

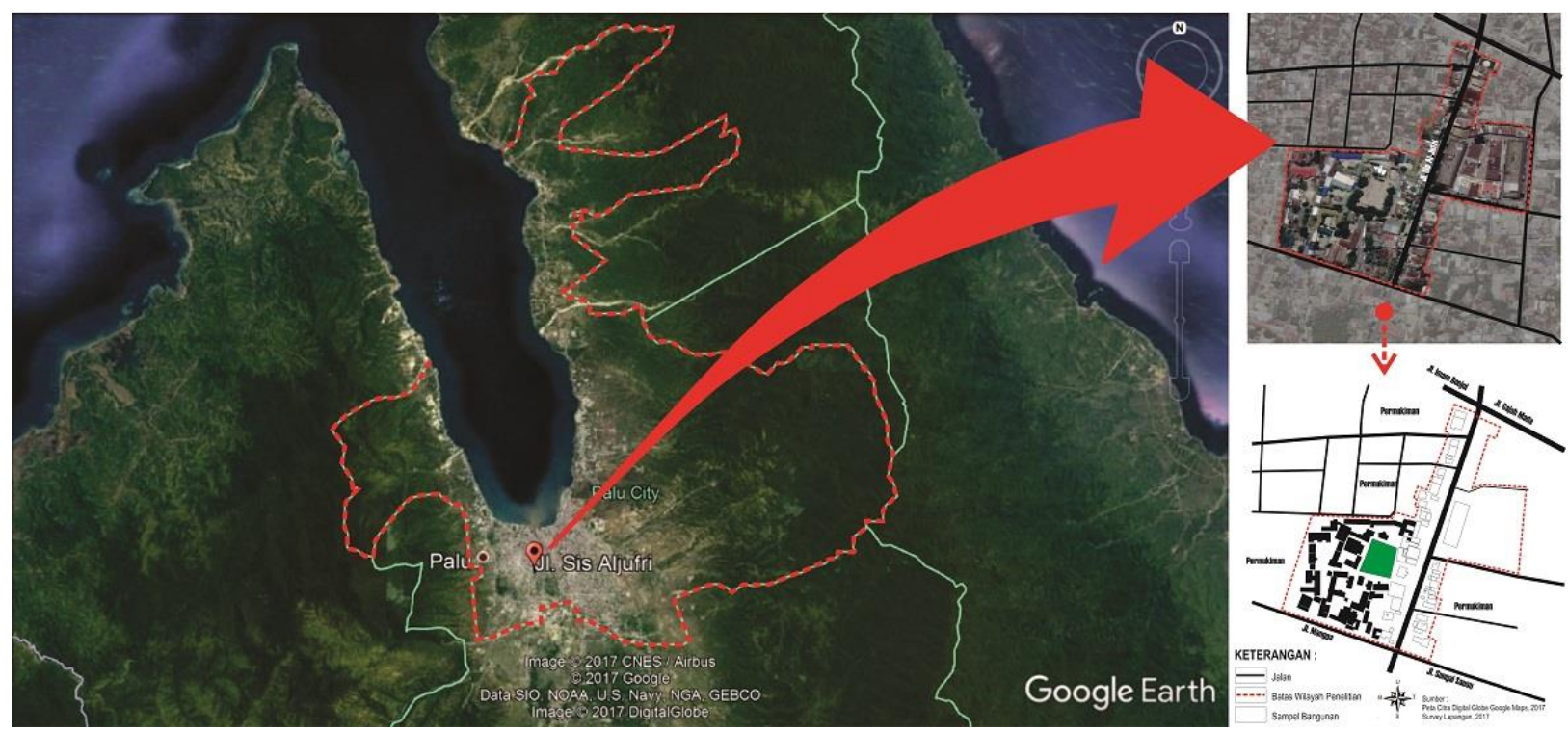

Gambar 1. Peta Segmen I Koridor Sis Al-Jufri (Hasil Analisis, 2017)

\section{HASIL DAN PEMBAHASAN}

Perubahan fisik ruang merupakan tolok ukur utama yang menujukkan pesat atau tidaknya perkembangan suatu kawasan. Semakin pesat perkembangan kawasan ditunjukkan dengan tingginya perubahan fisik yang terjadi. Secara umum, perubahan morfologi ruang pada koridor Sis Al-Jufri terjadi karena perubahan peruntukkan lahan dari permukiman menjadi kawasan perdagangan dan jasa, sehingga bangunan hunian berubah fungsi menjadi bangunan komersial untuk kegiatan perdagangan dan jasa mengikuti tuntutan pasar. Selain itu juga dikarenakan keberadaan Kompleks Pertokoan Palu Plaza sebagai salah satu pusat perbelanjaan terbesar di Kota Palu, sehingga mempengaruhi kawasan sekitarnya.

\subsection{Analisis Perubahan Morfologi Ruang Pada Koridor Sis Al-Jufri}

\subsubsection{Perubahan Penggunaan Lahan}

Penggunaan lahan sebagai salah satu produk kegiatan manusia memang menunjukkan variasi yang besar, baik dalam kota lokal maupun di dalam kota regional. Menurut Yunus (2015), Pemahaman bentukbentuk penggunaan lahan yang mewarnai daerah terbangun (built-up area). Berdasarkan RTRW Kota Palu Tahun 2010 - 2030, koridor Sis Al-Jufri ditetapkan sebagai kawasan campuran yaitu permukiman, 
pengembangan pusat perbelanjaan dan toko modern, serta sebagai kawasan pariwisata budaya, yaitu kawasan wisata religi Sis Al-Jufri.

Tabel 2. Penggunaan Lahan Segmen I Koridor Sis Al-Jufri Tahun 2005, 2011 Dan 2017 (Hasil Analisis, 2017)

\begin{tabular}{|c|c|c|c|c|c|c|}
\hline GUNA LAHAN & $\begin{array}{c}\text { TAHUN } \\
2005\end{array}$ & $\begin{array}{c}\text { PERSEN- } \\
\text { TASE }\end{array}$ & $\begin{array}{c}\text { TAHUN } \\
2011\end{array}$ & $\begin{array}{c}\text { PERSEN- } \\
\text { TASE }\end{array}$ & $\begin{array}{c}\text { TAHUN } \\
2017\end{array}$ & $\begin{array}{c}\text { PERSEN- } \\
\text { TASE }\end{array}$ \\
\hline Permukiman & $3.47 \mathrm{Ha}$ & $49.57 \%$ & $1.50 \mathrm{Ha}$ & $21.43 \%$ & $0.21 \mathrm{Ha}$ & $3.00 \%$ \\
\hline Perdagangan dan Jasa & $2.51 \mathrm{Ha}$ & $35.86 \%$ & $2.95 \mathrm{Ha}$ & $42.14 \%$ & $3.82 \mathrm{Ha}$ & $54.57 \%$ \\
\hline Peribadatan & $0.09 \mathrm{Ha}$ & $0.24 \%$ & $0.24 \mathrm{Ha}$ & $3.43 \%$ & $0.24 \mathrm{Ha}$ & $3.43 \%$ \\
\hline Pendidikan & $0.93 \mathrm{Ha}$ & $13.29 \%$ & $2.31 \mathrm{Ha}$ & $33.00 \%$ & $2.73 \mathrm{Ha}$ & $39.00 \%$ \\
\hline TOTAL & $7.00 \mathrm{Ha}$ & $100 \%$ & $7,00 \mathrm{Ha}$ & $100 \%$ & $7,00 \mathrm{Ha}$ & $100 \%$ \\
\hline
\end{tabular}

Penggunaan lahan perdagangan dan jasa pada Koridor Sis Al-Jufri mengalami penambahan yang paling banyak, yaitu dari luas sebanyak 2,51 Ha menjadi 3,82 Ha atau sebesar 18,71\%. Sedangkan penggunaan lahan permukiman mengalami pengurangan dari luas sebanyak 3,47 Ha menjadi 0,21 $\mathrm{Ha}$ atau sebesar 46,57\%. Dari 59 sampel bangunan sebanyak 45 unit bangunan yang mengalami perubahan penggunaan lahan, yaitu permukiman menjadi perdagangan dan jasa, dan sebanyak 14 unit bangunan yang tidak mengalami perubahan penggunaan lahan. Dalam pelaksanaan produk tata ruang, sering terjadi ketidaksesuaian antara penggunaan lahan dengan rencana peruntukkannya (Khadiyanto, 2005).

\section{TAHUN 2005}

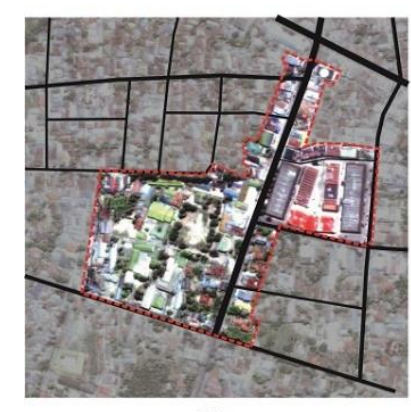

TAHUN 2011

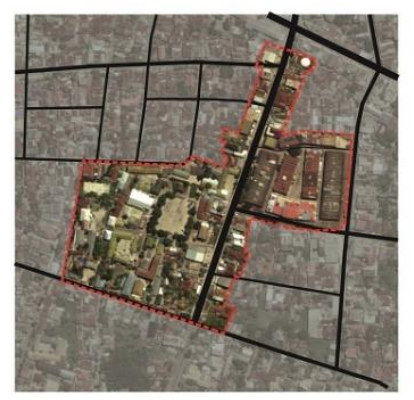

TAHUN 2017

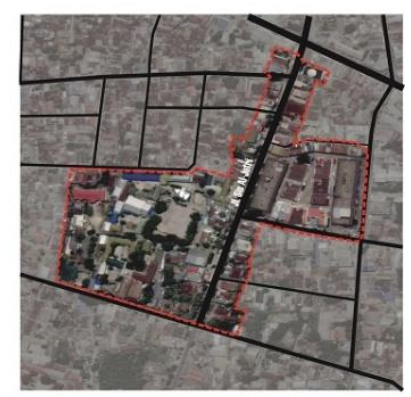

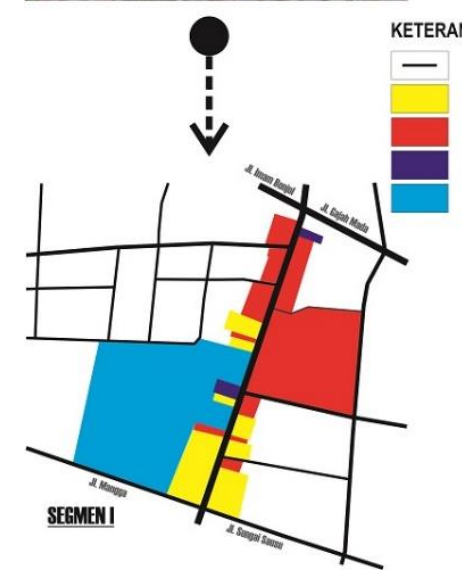

KETERANGAN :

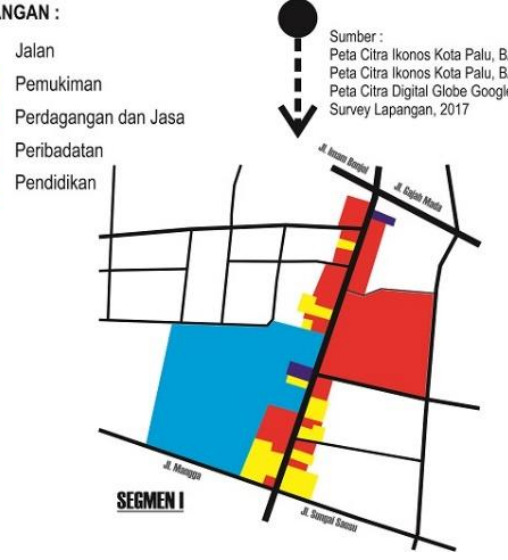

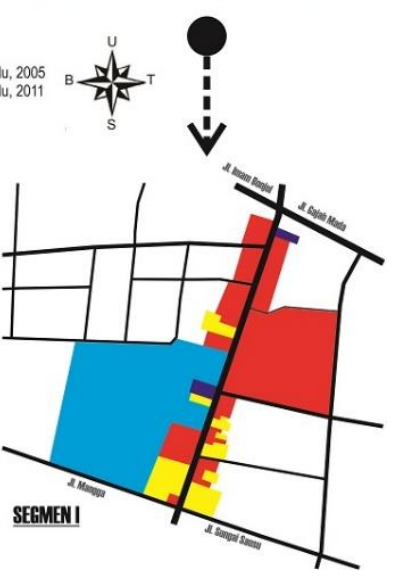

Gambar 2. Penggunaan Lahan Segmen I Koridor Sis Al-Jufri (Hasil Analisis, 2017)

\subsubsection{Perubahan Fungsi Bangunan}

Berdasarkan Peraturan Daerah Kota Palu No. 6 Tahun 2011 tentang bangunan gedung, fungsi bangunan gedung dibagi menjadi fungsi hunian, fungsi keagamaan, fungsi usaha, fungsi sosial dan budaya (pelayanan pendidikan). Fungsi usaha pada Koridor Sis Al-Jufri mengalami penambahan yang paling banyak, yaitu dari 24 unit bangunan menjadi sebanyak 41 unit bangunan. Dari 59 sampel bangunan 
sebanyak 3 unit bangunan yang mengalami perubahan fungsi bangunan, yaitu bangunan dengan funsgi hunian menjadi fungsi usaha, dan sebanyak 56 unit bangunan yang tidak mengalami perubahan fungsi bangunan. Koridor Sis Al-Jufri dengan fungsi mix-used, sangat wajar jika terjadi perubahan fungsi bangunan karena merupakan salah satu dinamika perkembangan kota yang berlangsung pesat. Perubahan fungsi bangunan segmen i koridor Sis Al-Jufri Tahun 2005, 2011 Dan 2017 dapat dilihat dalam Tabel 3 dan Gambar 3.

Tabel 3. Fungsi Bangunan Segmen I Koridor Sis Al-Jufri Tahun 2005, 2011 Dan 2017 (Hasil Analisis, 2017)

\begin{tabular}{cccc}
\hline FUNGSI BANGUNAN & TAHUN 2005 & TAHUN 2011 & TAHUN 2017 \\
\hline Hunian & 14 unit & 13 unit & 11 unit \\
Keagamaan & 2 unit & 2 unit & 2 unit \\
Usaha & 24 unit & 31 unit & 41 unit \\
Sosial dan budaya & 5 unit & 5 unit & 5 unit \\
\hline TOTAL & $\mathbf{4 5}$ unit & 51 unit & 59 unit \\
\hline
\end{tabular}
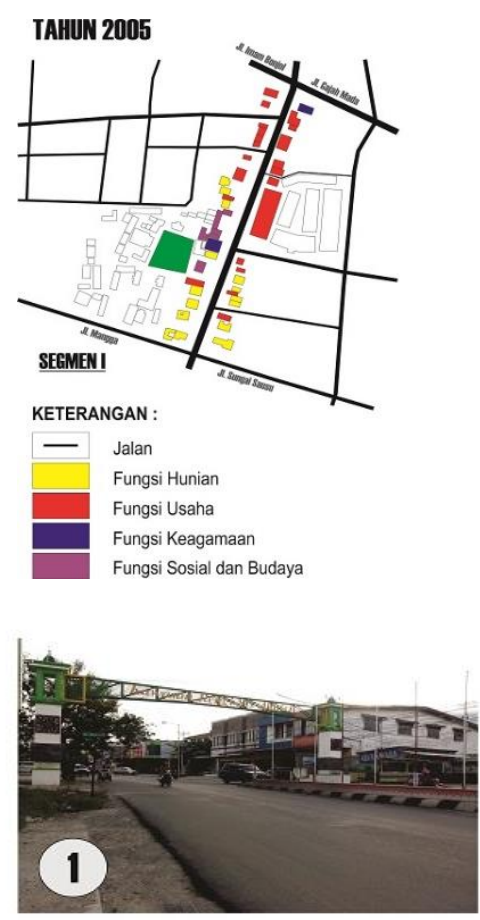

Perdagangan dan jasa dengan fungsi usaha berupa deretan ruko-ruko pada sisi bagian barat dari koridor
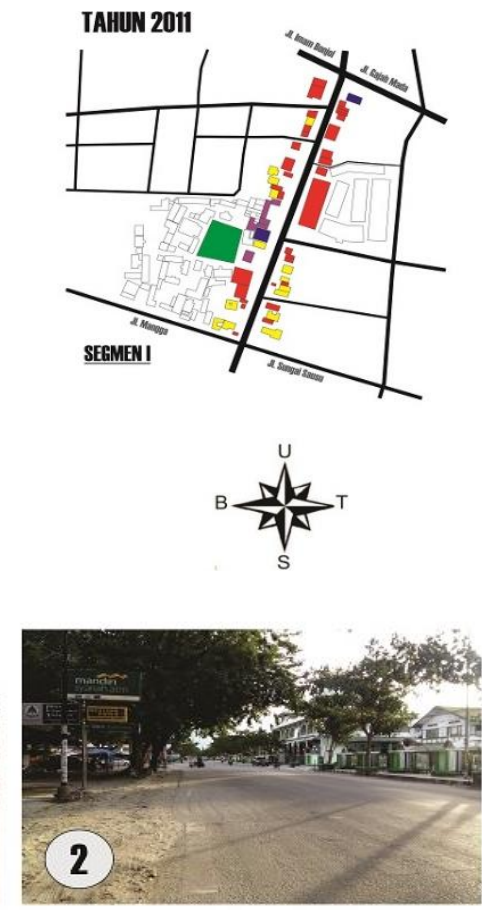

Kawasan pendidikan Yayasan Al-Khairaat yan berhadapan langsung dengan kompleks pertokoan Palu Plaza.

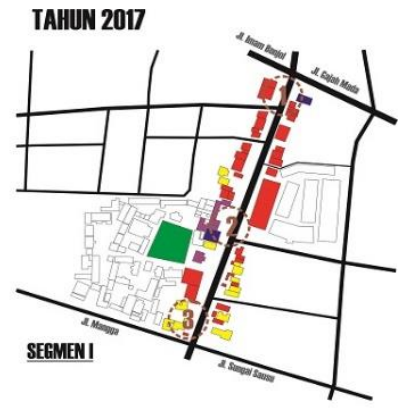

Sumber: Peta Citra lkonos Kota Palu, BAPPEDA Kota Palu, 20 Peta Citra Digital Globe Google Maps, 2017
Survey Lapangan, 2017

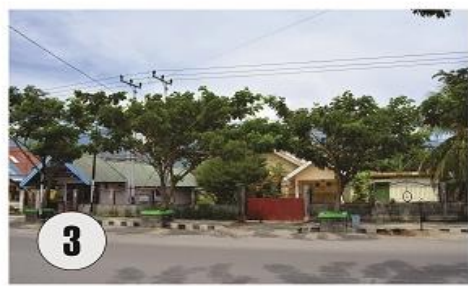

Keberadaan hunian berupa rumah tinggal, menyebar di sepanjang Koridor Sis Al-Jufri Segmen I

Gambar 3. Fungsi Bangunan Segmen I Koridor Sis Al-Jufri (Hasil Analisis, 2017)

\subsubsection{Perubahan Ketinggian Bangunan}

Berdasarkan Peraturan Daerah Kota Palu No. 6 Tahun 2011 tentang Bangunan Gedung, klasifikasi ketinggian meliputi bangunan bertingkat rendah adalah bangunan dengan ketinggian 2 (dua) lantai; bangunan bertingkat sedang adalah bangunan dengan ketinggian 3 (tiga) sampai dengan 5 (lima) lantai dan bangunan bertingkat sedang semi permanen ketinggian maksimal 2 (dua) lantai; serta bangunan bertingkat tinggi adalah bangunan dengan ketinggian bangunan lebih dari 6 (enam) lantai sampai dengan 12 (dua belas) lantai. Ketinggian bangunan pada Koridor Sis Al-Jufri mengalami penambahan yang paling 
banyak, yaitu pada bangunan berlantai 1 dari 18 unit bangunan menjadi sebanyak 25 unit bangunan. Dari 59 sampel bangunan sebanyak 20 unit bangunan yang mengalami perubahan ketinggian bangunan, yaitu menambah ketinggian bangunan dari bangunan berlantai 1 menjadi bangunan berlantai 2 atau 3 guna memenuhi kebutuhan ruang, dan sebanyak 39 unit bangunan yang tidak mengalami perubahan ketinggian bangunan. Pengaturan batas ketinggian bangunan merupakan hal kompleks dalam suatu sistem perencanaan kota, tidak terkecuali juga penataan ketinggian pada koridor. Dalam pengaturannya akan berdampak pada wujud rancang bangun, serta memiliki kontribusi tersendiri terhadap konsep pembangunan yang berkelanjutan (Suartika, 2010). Pengaturan batas ketinggian bangunan diperlukan untuk pengendalian dan pengaturan besaran bangunan dalam suatu kawasan tertentu didalam pemberinan izin mendirikan bangunan (Heryanto, 2011).

Tabel 4. Ketinggian Bangunan Segmen I Koridor Sis Al-Jufri Tahun 2005, 2011 dan 2017

\begin{tabular}{lccc}
\multicolumn{4}{c}{ (Hasil Analisis, 2017) } \\
\hline KETINGGIAN & TAHUN & TAHUN & TAHUN \\
BANGUNAN & $\mathbf{2 0 0 5}$ & $\mathbf{2 0 1 1}$ & $\mathbf{2 0 1 7}$ \\
\hline Bangunan berlantai 1 & 18 unit & 20 unit & 25 unit \\
Bangunan berlantai 2 & 24 unit & 27 unit & 27 unit \\
Bangunan berlantai 3 & 3 unit & 4 unit & 7 unit \\
\hline TOTAL & 45 unit & $\mathbf{1 5 0}$ & $\mathbf{1 6 9}$ \\
\hline
\end{tabular}

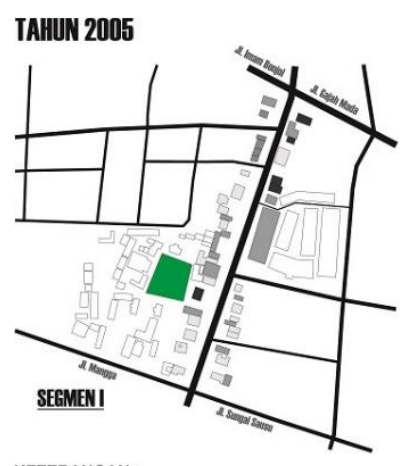

KETERANGAN :
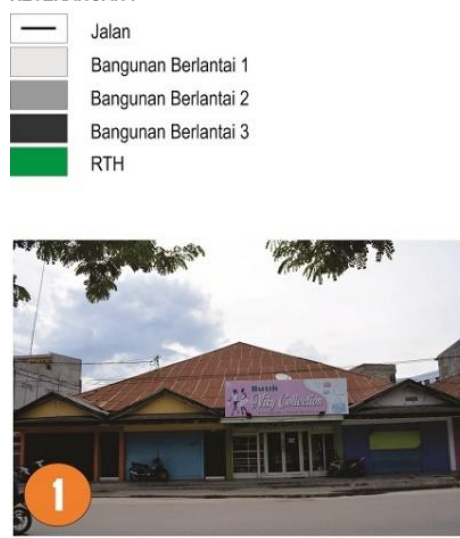

Bangunan Berlantai 1
TAHUN 2011
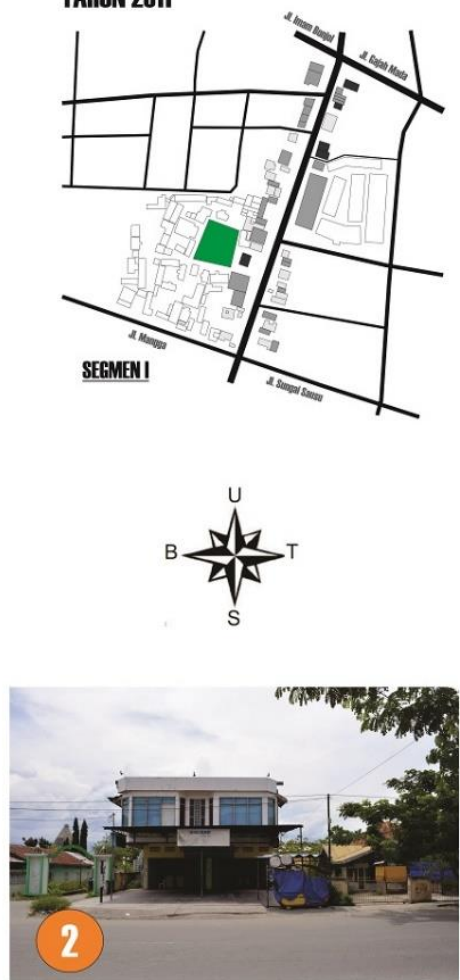

Bangunan Berlantai 2

\section{TAHUN 2017}

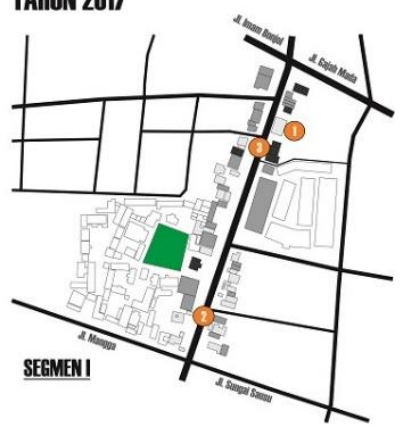

Sumber: Peta Citra lkonos Kota Palu, BAPPEDA Kota Palu, 2005
Peta Citra Ikonos Kota Palu, BAPPEDA Kota Palu, 2011
Peta Citra Digital Globe Google Maps, 2017 Peta Citra Digital Globe Google Maps, 2017
Survey Lapangan, 2017

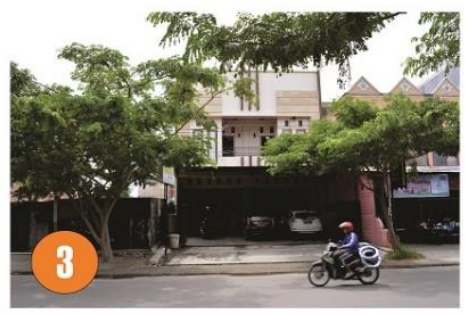

Bangunan Berlantai 3

Gambar 4. Ketinggian Bangunan Segmen I Koridor Sis Al-Jufri (Hasil Analisis, 2017)

\subsubsection{Perubahan Tampilan Bangunan}

Berdasarkan Laporan RTBL Kawasan Wisata Religi Sis Al-Jufri, tampilan visual bangunan di sepanjang koridor Sis Al-Jufri diharapkan sebagai pembentuk citra kawasan sebagai kawasan religi. Namun, tampilan 
bangunan pada koridor ini sangat beragam mulai dari menampilkan karakter budaya lokal, aristektur islam, karakter yang menampilkan ciri arsitektur berdasarkan awal aspek historis pertumbuhan kawasan (arsitektur tahun 60-an), hingga yang bergaya modern dan minimalis.

Tabel 5. Tampilan Bangunan Segmen I Koridor Sis Al-Jufri Tahun 2005, 2011 dan 2017

(Hasil Analisis, 2017)

\begin{tabular}{lccc}
\hline \multicolumn{1}{c}{ TAMPILAN BANGUNAN } & TAHUN & TAHUN & TAHUN \\
& $\mathbf{2 0 0 5}$ & $\mathbf{2 0 1 1}$ & $\mathbf{2 0 1 7}$ \\
\hline Gaya arsitektur lokal & 6 unit & 7 unit & 10 unit \\
Gaya arsitektur islam & 7 unit & 8 unit & 8 unit \\
Gaya arsitektur modern tahun 1960-an & 11 unit & 11 unit & 14 unit \\
Gaya arsitektur modern dan minimalis & $\mathbf{2 1 ~ u n i t ~}$ & $\mathbf{2 5}$ unit & 27 unit \\
\hline TOTAL & $\mathbf{4 5}$ unit & $\mathbf{5 1 ~ u n i t ~}$ & $\mathbf{5 9}$ unit \\
\hline
\end{tabular}

Tampilan bangunan pada Koridor Sis Al-Jufri mengalami penambahan yang paling banyak, yaitu pada bangunan bergaya arsitektur modern dan minimalis, yaitu dari 21 unit bangunan menjadi sebanyak 27 unit bangunan. Dari 59 sampel bangunan sebanyak 10 unit bangunan yang mengalami perubahan tampilan bangunan dan sebanyak 49 unit bangunan yang tidak mengalami perubahan tampilan bangunan. Perubahan terhadap tampilan bangunan dipengaruhi oleh faktor ekonomi, sosial, budaya, lingkungan dan juga mengikuti trend gaya bangunan yang sedang berkembang pada periode/ waktu tertentu (perubahan waktu). Selain itu tampilan bangunan juga dapat memberikan identitas terhadap suatu bangunan kapan bangunan tersebut dibangun.
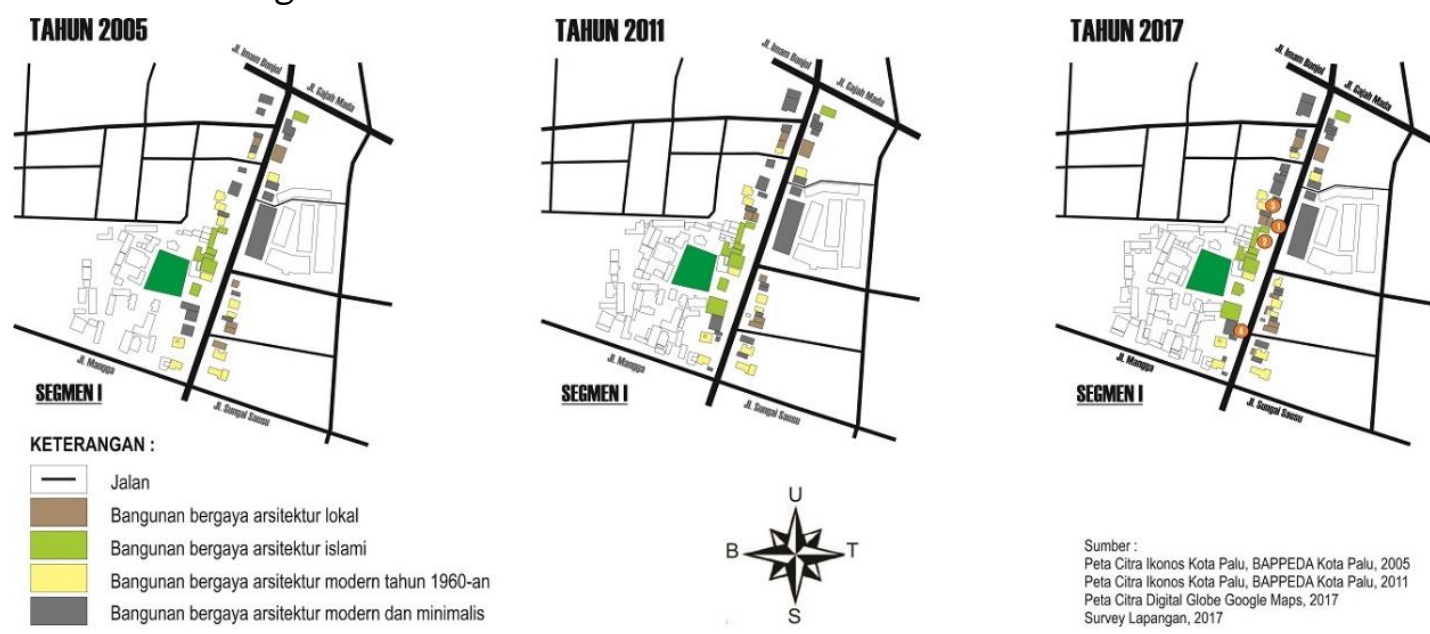

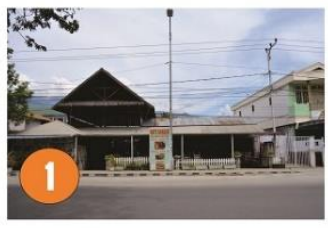

Bangunan bergaya arsitektur lokal

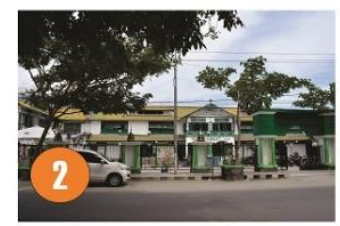

Bangunan bergaya arsitektur islam

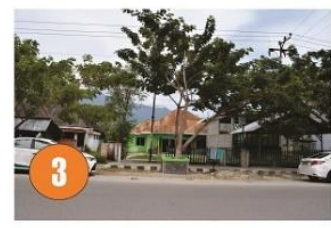

Bangunan bergaya arsitektur modern tahun 1960-an

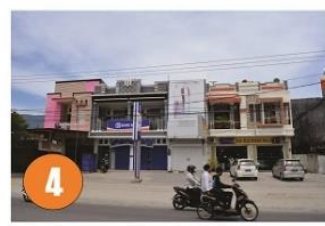

Bangunan bergaya arsitektur modern dan minimalis

Gambar 5. Tampilan Bangunan Segmen I Koridor Sis Al-Jufri Tahun 2005, 2011 dan 2017

(Hasil Analisis, 2017) 


\subsubsection{Perubahan Ukuran / Luasan Bangunan}

Berdasarkan Peraturan Daerah Kota Palu No. 6 Tahun 2011 tentang bangunan gedung, klasifikasi ketinggian bangunan gedung menurut luasnya meliputi: bangunan dengan luas $<100 \mathrm{~m}^{2}$; bangunan dengan luas $100-250 \mathrm{~m}^{2}$; bangunan dengan luas $251-500 \mathrm{~m}^{2}$; bangunan dengan luas $501-1000 \mathrm{~m}^{2}$; dan bangunan dengan luas $>1000 \mathrm{~m}^{2}$.

Tabel 6. Ukuran / Luasan Bangunan Segmen I Koridor Sis Al-Jufri Tahun 2005, 2011 Dan 2017 (Hasil Analisis, 2017)

\begin{tabular}{lccc}
\hline $\begin{array}{c}\text { UKURAN } \\
\text { BANGUNAN }\end{array}$ & $\begin{array}{c}\text { TAHUN } \\
\mathbf{2 0 0 5}\end{array}$ & $\begin{array}{c}\text { TAHUN } \\
\mathbf{2 0 1 1}\end{array}$ & $\begin{array}{c}\text { TAHUN } \\
\mathbf{2 0 1 7}\end{array}$ \\
\hline$<100 \mathrm{~m}^{2}$ & 1 unit & 4 unit & 9 unit \\
$100-250 \mathrm{~m}^{2}$ & 6 unit & 4 unit & 11 unit \\
$251-500 \mathrm{~m}^{2}$ & 21 unit & 22 unit & 17 unit \\
$501-1000 \mathrm{~m}^{2}$ & 12 unit & 13 unit & 12 unit \\
$>1000 \mathrm{~m}^{2}$ & 5 unit & 8 unit & 10 unit \\
\hline TOTAL & $\mathbf{4 5}$ unit & $\mathbf{5 1}$ unit & $\mathbf{5 9}$ unit \\
\hline
\end{tabular}

Ukuran / luasan bangunan pada Koridor Sis Al-Jufri mengalami penambahan yang paling banyak, yaitu pada bangunan dengan luas $<100 \mathrm{~m}^{2}$, yaitu dari 1 unit bangunan menjadi sebanyak 9 unit bangunan. Dari 59 sampel bangunan sebanyak 29 unit bangunan yang mengalami perubahan ukuran / luasan bangunan, yaitu melakukan penambahan ruangan baik ke depan, belakang, atas ataupun ke samping dan sebanyak 30 unit bangunan yang tidak mengalami perubahan ukuran / luasan bangunan. Besar bangunan dapat diartikan sebagai ukuran bangunan / luasan bangunan yang merupakan bentuk dari massa bangunan (Shirvani, 1985).
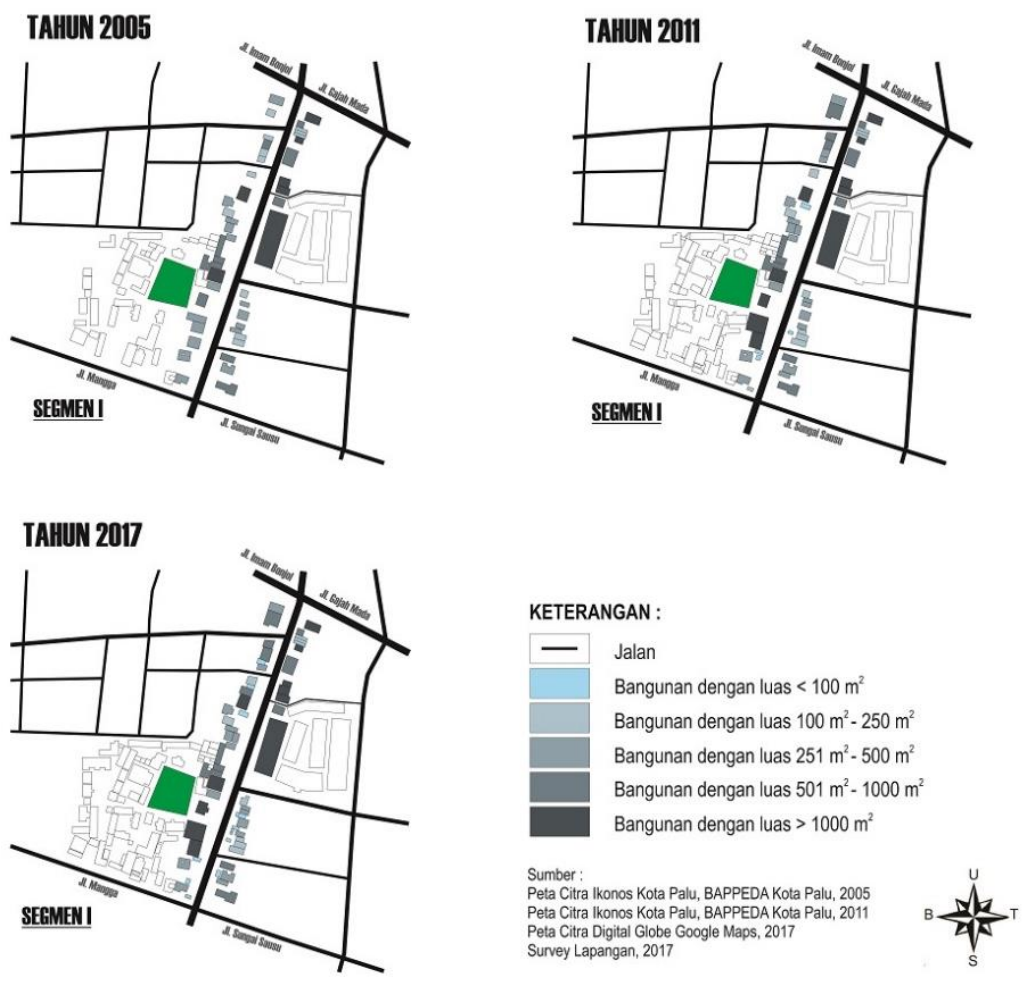

Gambar 6. Ukuran / Luasan Bangunan Segmen I Koridor Sis Al-Jufri Tahun 2005, 2011 Dan 2017 (Hasil Analisis, 2017) 
Berdasarkan hasil analisis diatas, maka perubahan morfologi ruang pada Koridor Sis Al-Jufri adalah tingkat perubahan sedang dengan perubahan sebesar $34,46 \%$.

\subsection{Faktor-Faktor Yang Mempengaruhi Perubahan Morfologi Ruang Pada Koridor Sis Al-Jufri}

Perubahan morfologi dalam perkembangan suatu kota tidak dapat dihindari. Perubahan tersebut dapat dipengaruhi oleh faktor fisik lahan, faktor ekonomi, faktor sosial dan budaya masyarakat. Adapun faktor-faktor yang mempengaruhi perubahan morfologi ruang pada Koridor Sis Al-Jufri terdiri dari faktor sosial (asal daerah, lama bermukim dan kepemilikan bangunan), faktor ekonomi (pekerjaan dan pendapatan) dan faktor kebijakan (kepemilikan IMB, pengaturan GSB dan konstruksi bangunan). Untuk mengetahui pengaruh faktor-faktor tersebut terhadap perubahan morfologi ruang koridor maka perlu dianalisis dengan menggunakan analisis regresi logistik dengan memperhatikan nilai signifikan Omnibus Test, $R$ Squared, serta Hosmer dan Lemeshow Test kemudian membuat persamaan regresi dan menilai Odds Ratio untuk menguji hipostesis.

Tabel 7. Nilai Sig. Faktor yang Mempengaruhi Perubahan Morfologi Ruang Pada Segmen I Koridor Sis Al-Jufri (Hasil Analisis, 2017)

\begin{tabular}{|c|c|c|c|c|c|c|c|c|}
\hline \multirow{2}{*}{$\begin{array}{c}\text { PERUBAHAN } \\
\text { MORFOLOGI } \\
\text { RUANG }\end{array}$} & \multicolumn{5}{|c|}{ IILAI SIG. FAKTOR YANG MEMPENGARUHI } \\
\cline { 2 - 9 } & \multicolumn{3}{|c|}{$X_{1}$} & \multicolumn{2}{|c|}{$X_{2}$} & \multicolumn{3}{c|}{$X_{3}$} \\
\cline { 2 - 9 } & $X_{1}$ & $X_{1}$ & $X_{1}$ & $X_{2}$ & $X_{2}$ & $X_{31}$ & $X_{32}$ & $X_{3}$ \\
\hline$Y_{1}$ & 0.307 & 0.052 & 0.185 & 0.239 & 0.072 & 0.999 & 0.656 & 0.998 \\
\hline$Y_{2}$ & 0.914 & 0.113 & 0.028 & 0.998 & 0.611 & 0.997 & 0.996 & 0.996 \\
\hline$Y_{3}$ & 0.216 & 0.000 & 0.115 & 0.003 & 0.068 & 0.015 & 0.190 & 0.129 \\
\hline$Y_{4}$ & 0.190 & 0.042 & 0.135 & 0.310 & 0.073 & 0.999 & 0.388 & 0.998 \\
\hline$Y_{5}$ & 0.993 & 0.004 & 0.631 & 0.001 & 0.272 & 0.102 & 0.467 & 0.209 \\
\hline
\end{tabular}

Keterangan:

$\mathrm{X}_{1_{1}}:$ Asal Daerah
$\mathrm{X}_{2}:$ Lama bermukim
$\mathrm{X}_{1_{3}}:$ Kepemilikan bangunan
$\mathrm{X}_{1}:$ Pekerjaan
$\mathrm{X}_{2}:$ Pendapatan
$\mathrm{X}_{3_{1}}:$ Kepemilikan IMB
$\mathrm{X}_{3_{2}}:$ Pengaturan $\mathrm{CSB}$
$\mathrm{X}_{3}:$ Konstruksi bangunan

Y1: Perubahan guna lahan

$Y_{2}$ : Perubahan fungsi bangunan

$\mathrm{Y}_{3}$ : Perubahan ketinggian bangunan

$\mathrm{Y}_{4}$ : Perubahan tampilan bangunan

$Y_{5}$ : Perubahan ukuran bangunan

Y6: Ketersediaan ruang terbuka privat

Berdasarkan hasil analisis regresi logistik, dengan tingkat kepercayaan yang digunakan adalah $95 \%$, jadi tingkat kesalahan $\alpha=5 \%$ atau 0,05. Jika sig $<0,05=\mathrm{H}_{0}$ ditolak atau $\mathrm{H}_{\mathrm{a}}$ diterima, ada pengaruh signifikan dari variabel $X$ terhadap variabel $Y$. Jika sig $>0,05=H_{0}$ diterima atau $H_{a}$ ditolak, tidak ada pengaruh signifikan dari variabel $\mathrm{X}$ terhadap variabel $\mathrm{Y}$.

Maka perubahan morfologi ruang Koridor Sis Al-Jufri berdasarkan nilai signifikan, yaitu :

- Nilai sig perubahan ketinggian bangunan 0,000 <0,05. Nilai sig perubahan tampilan bangunan $0,042<0,05$. Nilai sig perubahan ukuran bangunan $0,004<0,05$, sehingga dengan demikian dapat disimpulkan bahwa ada pengaruh signifikan dari variabel lama bermukim $\left(\mathrm{X}_{2}\right)$ terhadap variabel perubahan ketinggian bangunan ( $\left.\mathrm{Y}_{3}\right)$, perubahan tampilan bangunan ( $\left.\mathrm{Y}_{4}\right)$ dan perubahan ukuran bangunan ( $\left.\mathrm{Y}_{5}\right)$.

- Nilai sig perubahan fungsi bangunan 0,028 <0,05, sehingga dapat disimpulkan bahwa ada pengaruh signifikan dari variabel kepemilikan bangunan $\left(\mathrm{X}_{3}\right)$ terhadap variabel perubahan fungsi bangunan (Y2). 
- Nilai sig perubahan ketinggian bangunan 0,003 <0,05. Nilai sig perubahan ukuran bangunan 0,001 $<0,05$, sehingga dapat disimpulkan bahwa ada pengaruh signifikan dari variabel pekerjaan $\left(\mathrm{X}_{2}\right)$ terhadap variabel perubahan ketinggian bangunan $\left(\mathrm{Y}_{3}\right)$ dan perubahan ukuran bangunan $\left(\mathrm{Y}_{5}\right)$.

- Nilai sig perubahan ketinggian bangunan 0,015<0,05, sehingga dapat disimpulkan bahwa ada pengaruh signifikan dari variabel kepemilikan IMB $\left(\mathrm{X}_{3_{1}}\right)$ terhadap variabel perubahan ketinggian bangunan $\left(\mathrm{Y}_{3}\right)$.

\section{KESIMPULAN}

Berdasarkan hasil analisis diatas, maka dapat ditarik kesimpulan, yaitu bahwa perubahan morfologi ruang yang terjadi pada Koridor Sis Al-Jufri terdiri dari perubahan terhadap guna lahan sebesar 76,27\%, perubahan fungsi bangunan sebesar 5,08\%, perubahan ketinggian bangunan sebesar 33,90 \%, perubahan tampilan bangunan sebesar 16,95\%, dan perubahan ukuran/ luasan bangunan sebesar 49,15\%. Dengan demikian secara keseluruhan perubahan morfologi ruang yang terjadi di Koridor Sis Al-Jufri yaitu tingkat perubahannya adalah sedang sebesar $34,46 \%$. Berdasarkan hasil analisis, salah satu perubahan morfologi ruang pada koridor dengan tingkat perubahan tinggi adalah perubahan guna lahan. Tetapi perubahan tersebut tidak dapat dipengaruhi secara signifikan oleh faktor sosial, ekonomi maupun kebijakan. Terkait hal tersebut, dapat ditarik kesimpulan bahwa perubahan morfologi ruang yang terjadi pada koridor Sis AlJufri masih dalam fase awal, sehingga belum mampu dipengaruhi oleh faktor-faktor tersebut.

Faktor-faktor yang mempengaruhi perubahan morfologi ruang pada Koridor Sis Al-Jufri secara signifikan yang pertama adalah faktor sosial, yaitu lama bermukim dan kepemilikan bangunan. Menurut Balestra, dkk (2013) bahwa masyarakat yang bermukim dengan status bangunan milik pribadi, maka waktu bermukimnya cenderung lebih lama. Sedangkan dengan status bangunan sewa / kontrak, waktu bermukimnya cenderung lebih singkat atau bersifat sementara. Dengan demikian, semakin lama waktu bermukim dengan status bangunan milik sendiri maka akan memberikan kecenderungan melakukan perubahan secara signifikan terhadap fisik bangunan yang dihuninya guna memenuhi kebutuhan ruang dan dapat memberikan kenyamanan. Faktor kedua adalah faktor ekonomi, yaitu pekerjaan. perubahan ekonomi masyarakat berhubungan dengan perubahan kondisi mata pencaharian, kondisi pendapatan, jumlah pengeluaran masyarakat, dan kemampuan masyarakat dalam menyisihkan uang untuk menabung guna keperluan perawatan dan pemeliharaan rumah. Pekerjaan merupakan faktor yang dapat menentukan tingkat pendapatan. Faktor ketiga adalah faktor kebijakan yang terdiri dari kepemilikan IMB. Menurut Peraturan Daerah Kota Palu No. 10 Tahun 2012 tentang Izin Mendirikan Bangunan, setiap kegiatan mendirikan, membuat/ mengubah, memperbaharui/ memperbaiki, menambah/ memperluas bangunan harus disertai dengan setifikat kepemilikan IMB. Namun kencenderungan perubahan fisik yang terjadi pada bangunan, tidak diikuti dengan perubahan sertifikat kepemilikan IMB. Sehingga masih banyak masyarakat yang melakukan pelanggaran terhadap kebijakan yang telah ditetapkan oleh pemerintah. Oleh karena itu diharapkan kepada pemerintah harus melakukan kegiatan sosialisasi untuk pengendalian dan pengawasan dalam pemanfaatan ruang kota terutama pada koridor Sis Al-Jufri.

\section{REFERENSI}

Anggraeni, N \& Broto S. (2015). Hubungan Perubahan Fisik Ruang dengan Kondisi Sosial Ekonomi Masyarakat di Kawasan Koridor Aglomerasi Mertoyudan, Kabupaten Magelang. Jurnal Wilayah dan Lingkungan, 3(2), 79-94. Doi:10.14710/jwl.3.2.79-94.

Balestra, C \& Sultan J. (2013). The Determinants of Residential Satisfaction and it's Relation with Wellbeing. Organisation for Economic Co-operation and Development : Working Paper 54.

Belly, Rayano. (2017). Persepsi Masyarakat Bermukim di Tepian Sungai Pemuatan Kecamatan Baamang Sampit Kabupaten Kotawaringin Timur. Tesis, Departemen Perencanaan Wilayah dan Kota, Universitas Diponegoro.

Heryanto, Bambang. (2011). Roh dan Citra Kota : Peran Perancangan Kota Sebagai Kebijakan Publik. Surabaya : Brilian International. 
Khadiyanto, Parfi. (2005). Tata Ruang Berbasis pada Kesesuaian Lahan. Semarang : Badan Penerbit Universitas Diponegoro.

Pawitro, Udjianto. (2012). Masyarakat Kampung Kota - Kondisi Pemukimannya dan Upaya Perbaikan Lingkungan Kampung Kota. Seminar Regional Pembangunan Jawa Barat.

Pemerintah Kota Palu. (2006). Rencana Tata Ruang Wilayah Kota Palu Tahun 2006 - 2025 Hasil Revisi. BAPPEDA Kota Palu.

Pemerintah Kota Palu. 2011. Peraturan Daerah Nomor 16 tentang Rencana Tata Ruang Wilayah Kota Palu Tahun 2010 - 2030. Palu.

Pemerintah Kota Palu. (2011). Peraturan Daerah Nomor 6 tentang Bangunan Gedung. Palu.

Pemerintah Kota Palu. (2011). Rencana Tata Bangunan dan Lingkungan Kawasan Wisata Religi Sis Al-Jufri.

Pemerintah Kota Palu. (2012). Peraturan Daerah Nomor 10 tentang Izin Mendirikan Bangunan. Palu

Sarwono, J \& Herlina B. (2012). Statistik Terapan Aplikasi Untuk Riset Skripsi, Tesis dan Disertasi Menggunakan SPSS, Amos dan Excel. Jakarta : Elex Media Komputindo.

Shirvani, Hamid. (1985). The Urban Design Process. New York : Van Nostrand Reinhold Company.

Suartika, G.A.M. (2010). Pengaturan Batas Ketinggian Bangunan Dalam Menjaga Keberlanjutan Bentang Alam dan Lingkungan Terbangun. Jurnal Bumi Lestari 10(1), 146-158.

Sugiyono. (2015). Metode Penelitian Manajemen. Bandung : Alfabeta.

Yunus, Hadi, S. (2015). Struktur Tata Ruang Kota. Yogyakarta : Pustaka Pelajar. 